\title{
Significance of Brooding to the Energy Demands of Alaskan Rock Ptarmigan Chicks
}

\author{
JOHN B. THEBERGE ${ }^{1}$ and GEORGE C. WEST $^{2}$
}

\begin{abstract}
Rock ptarmigan (Lagopus mutus) chicks are brooded periodically during the first few days of life; longer in cold and rainy weather. Computed minimum foraging time in adverse weather conditions is 96 minutes/24 hours. Crop analysis and calorimetry of the 6 major food items show that a full crop may contain up to $0.47 \mathrm{kcals}$. Energy requirements were calculated for both an 18-gram chick and a 30-gram chick. The 18-gram chick required between 34 and 50 crop loads per 24 hours. With 96 minutes foraging time, and the observed pecking rates, this was considered possible. The 30gram chick required twice as much foraging time but since it was approaching homeothermy, it was tentatively concluded that neither was that chick being handicapped by brooding. Vagaries in early survival of rock ptarmigan chicks, therefore, are not due to differences in post-hatch weather.
\end{abstract}

RÉSUMÉ: Conséquences de la couvaison sur la demande en énergie chez des poussins du Lagopède des rochers en Alaska. Pendant les premiers jours de leur vie, les poussins du Lagopède des rochers (Lagopus mutus) sont couvés périodiquement et plus longtemps par temps froid et pluvieux. On a calculé que dans des conditions de mauvais temps, $96 \mathrm{~min} / 24 \mathrm{~h}$ sont consacrées à la recherche de nourriture. L'analyse et la calorimétrie de la cueillette des 6 aliments majeurs montrent qu'une cueillette complète peut donner jusqu'à $0.47 \mathrm{kcal}$. Les auteurs ont calculé la demande en énergie d'un poussin de 18 grammes et d'un autre de 30 grammes. Le premier a besoin de 34 à 50 cueillettes par 24 heures. On peut considérer que ceci est possible avec 96 minutes de temps de cueillette et selon les vitesses de becquetage observées. Le poussin de $\mathbf{3 0}$ grammes demande un temps de cueillette deux fois plus long mais comme il approche l'homéothermie, on peut conclure expérimentalement que ni l'un ni l'autre poussin n'est handicapé par la couvaison. Ainsi, les variations dans la survivance infantile chez les poussins du Lagopède des rochers ne sont pas dues à des différences dans l'état du temps après l'éclosion.

РЕЗЮМЕ. Значение согревания птенчов куропатки тундрлной на Аляске с точки зрения $n x$ әнергетических потребностей. Птенцы куропатки тундряной (Lagopus mutus) периодически согревағтся матерью в течение нескольких первых дней живни, более продолжительно в холодную и дождливую погоду. Вычисленное минимальное время кормёжки в условиях неблагоприятной потоды составляет 96 минут в сутки. Аналив зоба и калориметрирование 6-ти основных пищевых компонент показывает, что полный зоб может содержать до 0.47 ккал. Энергетические потребности были рассчитаны для птенцов весом 18г и 30г. Для птенца, весящего 18г, количество пищи в сутки должно составлять от 34 до 50 объёмов зоба. Показано, что при продолжительности кормёжки 96 минут и наблюдаемых скоростях клевания собрать такое количество пищи вполне возможно. Для птенца, весящего 30г, необходимо вдвое более продолжительное время кормёжки. Сделан вывод, что изменения степени выживаемости птенцов на ранней стадии их развития связаны, по-видимому, не с различиями погодных условий в период после их выведения, а с другими факторами.

1Faculty of Environmental Studies, University of Waterloo, Ontario, Canada.

2Institute of Arctic Biology, University of Alaska, Fairbanks, U.S.A. 


\section{INTRODUCTION}

Chicks of most species of galliform birds are brooded periodically during early life (Koskimies 1962). Brooding, therefore, can be viewed as a behavioural mechanism which contributes to the reduction of early chick mortality since newly hatched chicks are not able to maintain a high and constant body temperature at the low ambient temperatures which often occur during the hatching period. However, while chicks are being brooded by the hen, they lose time that could be spent in foraging for food.

Zwickel (1967) showed that low ambient temperatures plus rain increased brooding time which resulted in reduced foraging time for blue grouse chicks (Dendragapus obscurus) on Vancouver Island, but he concluded that this did not lower the survival rate of the chicks. In contrast, Marcstrom (1960), in his study of capercaillie (Tetrao urogallus) in Sweden, concluded that excessive brooding during unfavourable weather resulted in starvation of the young, so much so that this was a major determinant of population levels in that species. Similarly, Boag (1966) found a correlation between weather and chick survival in blue grouse in Alberta.

In the subarctic alpine of interior Alaska, where long periods of unpredictable low temperatures and rain or snow sometimes occur during the hatching period, weather may affect chick mortality directly or indirectly through increased brooding and decreased foraging by chicks. In this study, we describe the brooding behaviour of adult female rock ptarmigan (Lagopus mutus) at Eagle Creek, Alaska, and test the hypothesis that time spent by chicks being brooded adversely affects the ability of chicks to obtain sufficient energy for survival.

\section{STUDY AREA}

The study area is representative of the extensive rolling subarctic alpine tundra in central Alaska and lies 100 miles north-east of Fairbanks near mile 106 of the Steese Highway $\left(65^{\circ}\right.$ N., $145^{\circ}$ W.). Rock ptarmigan have been studied here intensively by Weeden since 1960 (Weeden and Theberge 1972). Elevations vary from 800 to 1,350 metres. Hill tops are covered primarily with mountain avens (Dryas octopetala) and fragmented rock (schist); mid-slopes by dwarf birch (Betula nana) and willow (Salix spp.) normally less than $30 \mathrm{~cm}$. high, and sedges and grasses; lower slopes with bilberry (Vaccinium uliginosum) and higher birch and willow which merge into the taiga forest of black and white spruce (Picea mariana, $P$. glauca).

The climate is continental subarctic. Precipitation averages less than $38 \mathrm{~cm}$. per year. The frost-free period usually extends from early June to mid August.

\section{METHODS}

In 1968 and 1969, over 18 hours of undisturbed observations were made on 4 wild ptarmigan hens and broods. Three of these hens were fitted with telemetric transmitters, each weighing 24 grams including battery, and delivering signals 
from 150 to $151 \mathrm{MHz}$ (Marshall 1960). The flexible loop antenna, which curved over the bird's back, altered the pitch of the signal when the bird moved, allowing interpretation of behaviour from up to a mile away. As concluded in studies using similar equipment, we found no evidence that the radio transmitters altered behaviour (Marshall 1963; Robel 1969; Lance 1970). The exact time of hatch was known from periodic observations at nests for all broods.

Crops were collected from 33 chicks less than 6 days old, representing 10 broods. Crop contents were examined when fresh or after having been frozen. Contents were sorted, identified, and air-dried at $80^{\circ} \mathrm{C}$. to a constant weight. Caloric values of the major food items were obtained by pooling each item of the same species and burning the aggregate in a Phillipson microbomb calorimeter (Phillipson 1964).

\section{RESULTS}

Brooding Behaviour as Influenced by Weather, Age of Chicks, and Time of Day

Normal brooding behaviour consisted of periods in which all chicks were under the stationary hen. Periodically the chicks left the hen to forage. When foraging, the chicks pecked very rapidly as they moved out from the hen, but they rarely went beyond 5 metres. The hen also usually moved slowly, feeding on the way. Distances moved by hens during any one foraging period between brooding varied from less than 0.3 metres to 100 metres. Chicks usually all returned to the hen at the same time even though scattered.

The mean daily temperature at ground level during the week following the peak of hatch in 1968 and 1969 ranged from 6.1 to $21.1^{\circ} \mathrm{C}$. (Table 1). The temperature in 1968 was 9 degrees C. colder than in 1969 (Table 1). Similarly, at Fairbanks, the mean temperature for the week following the peak of hatch in 1968 was 3.4 degrees C. below the 10-year mean from 1960 to 1969. Although Fairbanks is 100 miles away and more than 650 metres lower, temperatures there are representative of those at Eagle Creek (Haugen et al. 1970). Therefore the temperatures in Table 1 closely reflect the full range of daily means ever encountered by ptarmigan chicks immediately after hatch. Hatching dates are quite confined (Weeden 1963), always less than 2-weeks duration. Re-nesting is rare, and Weeden (1968) observed that ptarmigan adjust their breeding activity to coincide with spring weather as reflected by flowering dates of conspicuous plants (1969 was an exception, being unusually warm).

Temperature alone did not apparently affect foraging time. As shown in Table 2 , observations 1 and 7 were both made when the ambient temperature was $13.3^{\circ} \mathrm{C}$., but foraging times were 12.6 and 0 minutes respectively. Observation 7 was made at night, between 00:25 and 01:55, and although daylight persisted (sun was low on the horizon), chicks were brooded continuously.

Neither did age of chicks considered alone clearly affect foraging time. In observation 1 (Table 2), chicks were less than 12 hours old and foraged 12.6 minutes per hour, whereas in observation 2 chicks were 3 times as old and foraged only 8 minutes per hour. However, some reduction in length of foraging periods appeared to occur when chicks were young and temperature was low. 
TABLE 1. Temperatures $\left({ }^{\circ} \mathrm{C}\right.$.) for the week following peak of hatch of rock ptarmigan at Eagle Creek, Alaska 1968 and 1969.

\begin{tabular}{lrlll}
\hline & & \multicolumn{2}{c}{1969} \\
Date & $\begin{array}{r}\text { Daily } \\
\text { Mean }\end{array}$ & Date & $\begin{array}{c}\text { Daily } \\
\text { Mean }\end{array}$ \\
\hline 21 June & 6.1 & 17 June & 16.7 \\
22 June & 6.7 & 18 June & 17.8 \\
23 June & 10.6 & 19 June & 18.9 \\
24 June & 8.9 & 20 June & 21.1 \\
25 June & 11.6 & 21 June & 20.0 \\
26 June & 11.6 & 22 June & 18.9 \\
27 June & 11.6 & 23 June & 18.3 \\
Average & 9.6 & & 18.8 \\
\hline
\end{tabular}

TABLE 2. Observations of brooding of rock ptarmigan chicks at Eagle Creek, Alaska 1968 and 1969.

\begin{tabular}{|c|c|c|c|c|c|c|c|c|c|c|c|}
\hline $\begin{array}{l}\text { Observation } \\
\text { number }\end{array}$ & Date & Time & $\begin{array}{c}\text { Minutes of } \\
\text { observation }\end{array}$ & $\begin{array}{c}\text { Age of } \\
\text { chicks (hrs.) }\end{array}$ & $\begin{array}{l}\text { Mean Ambient } \\
\text { Temperature }\left({ }^{\circ} \mathrm{C}\right)\end{array}$ & Rain & $\begin{array}{c}\text { Foragi } \\
\text { Mear } \\
\text { (min) }\end{array}$ & $\begin{array}{l}\text { Periods } \\
\text { Length } \\
\text { (n) }\end{array}$ & $\begin{array}{r}\text { Broo } \\
\text { Mea } \\
\text { (min) }\end{array}$ & $\begin{array}{l}\text { iods } \\
\text { gth } \\
(\mathrm{n})\end{array}$ & $\begin{array}{c}\text { Foraging } \\
\text { time per } \\
\text { hour (min) }\end{array}$ \\
\hline 1 & 20 June 1968 & $\begin{array}{l}14: 36-17: 10 \\
18: 17-19: 09\end{array}$ & 206 & $<12$ & 13.3 & $t$ & 5.3 & (9) & 19.9 & (8) & 12.6 \\
\hline 2 & 22 June 1968 & $10: 21-13: 42$ & 201 & 43 & 5.0 & ++ & 2.5 & (11) & 15.7 & (11) & 8.3 \\
\hline 3 & 25 June 1968 & $15: 22-17: 30$ & 128 & $22-26$ & 10.0 & ++ & 3.2 & (4) & 28.7 & (4) & 6.0 \\
\hline 4 & 26 June 1968 & $09: 47-11: 35$ & 108 & 144 & 18.3 & + & cont. & (1) & 0 & (0) & cont. \\
\hline 7 & 21 June 1969 & $00: 25-01: 55$ & 90 & $<24$ & 13.3 & 0 & 0 & (0) & cont. & (1) & 0 \\
\hline
\end{tabular}

$+=$ light rain, $++=$ heavy rain

cont. $=$ continuous 


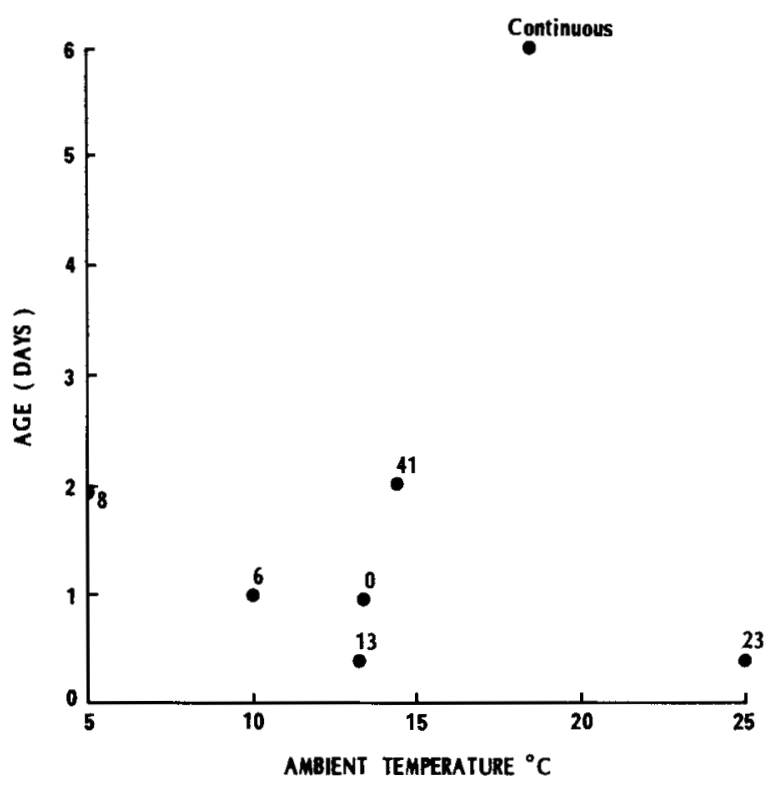

FIG. 1. The effect of ambient temperature and age of chicks on foraging time in young rock ptarmigan. Foraging times in minutes/hour are above plotted points.

One brood, when 48 hours old, foraged 41 minutes per hour when the ambient temperature was relatively warm $\left(14.4^{\circ} \mathrm{C}\right.$.). The same brood foraged only 6 minutes per hour when approximately 24 hours old when the ambient temperature was lower $\left(10^{\circ} \mathrm{C}\right.$. $)$. See Fig. 1 .

A period of continuous brooding apparently occurs during the period of low light intensity around midnight. Between 00:25 and 01:55 (observation 7, Table 2) chicks did not forage. However, chicks observed at the same ambient temperature but in the afternoon and evening rather than at "night" were allowed to forage (observation 1).

The data suggest that chicks may be brooded longer when rain is falling. Other than the "night" observation, the two shortest foraging times per hour occurred when heavy rain was falling. In observation 5 (Table 2) a light rain fell during the early period of observation and the sun came out during the later portion of the observation period. Although the temperature remained constant, the length of foraging periods increased from 4 and 5 minutes to 14 and 17 minutes.

Miscellaneous observations, plus observation 4 (Table 2) indicated that at 6 days of age, chicks were no longer brooded. This agrees with Anvik's (1969) conclusion drawn from tests of rock ptarmigan chicks (from Eagle Creek) in a cold chamber, that "effective homeothermy" is accomplished when chicks weigh between 35 and 40 grams (approximately 5 days old).

To conclude, the shortest daytime foraging period observed was 6 minutes per hour; this occurred in young chicks at low ambient temperature during rain.

\section{Chick Energetics}

ENERGY OBTAINED. During the first 6 days of life, ptarmigan chicks consumed 74 per cent vegetable matter, the remainder being invertebrates (Table 3). Flowers of Vaccinium made up the highest percentage (35.9). This was followed 
TABLE 3. Analysis of crop contents of rock ptarmigan chicks 1 to 6 days old.

\begin{tabular}{|c|c|c|c|}
\hline Item & $\begin{array}{l}\text { Plant } \\
\text { part }\end{array}$ & $\begin{array}{l}\% \text { Frequency } \\
\text { of occurrence }\end{array}$ & $\begin{array}{l}\% \text { oven } \\
\text { dry weight }\end{array}$ \\
\hline \multicolumn{4}{|l|}{ Plant } \\
\hline Moss & Capsule & 51.5 & 7.9 \\
\hline Carex sp. & Seed-head tips & 3.3 & .6 \\
\hline Vaccinium spp. 1 & & 63.6 & 35.9 \\
\hline Vaccinium uliginosum & Berry & 9.1 & 5.9 \\
\hline Vaccinium Vitis-idaea & Berry & 6.1 & 13.5 \\
\hline Pedicularis sp. & Leaf & 3.3 & .7 \\
\hline Polygonum viviparum & Bulbils & 18.2 & 3.3 \\
\hline Unidentified fragments & Leaf & $33: 3$ & 6.2 \\
\hline Total & & & 74.0 \\
\hline \multicolumn{4}{|l|}{ Invertebrate } \\
\hline Snail & & 6.1 & 7.0 \\
\hline Aranea & & 3.3 & .06 \\
\hline \multicolumn{4}{|l|}{ Coleoptera } \\
\hline Fam. Coccinellidae & & 3.3 & .8 \\
\hline Coleoptra larvae & & 3.3 & 1.1 \\
\hline Lepidoptera larvae & & 21.2 & 4.6 \\
\hline \multicolumn{4}{|l|}{ Diptera (adult) } \\
\hline Fam. Tipulidae & & 24.2 & \\
\hline Fam. Lauxaniidae & & 12.1 & \\
\hline Fam. Syrphidae & & 12.1 & \\
\hline Fam. Mycetophilidae & & 6.1 & \\
\hline Fam. Dolichopodidae & & 3.3 & \\
\hline Fam. Sepsidae & & 3.3 & \\
\hline Fam. Cecidomyidae & & 3.3 & \\
\hline Unidentified & & 18.2 & \\
\hline Total Diptera & & 60.6 & 11.1 \\
\hline \multicolumn{4}{|l|}{ Hymenoptera } \\
\hline Fam. Ichneumonidae & & 15.3 & .6 \\
\hline \multicolumn{4}{|l|}{ Homoptera } \\
\hline Fam. Cicadellidae & & 3.3 & .03 \\
\hline Fam. Aphididae & & 6.1 & .01 \\
\hline Unidentified larvae & & 6.1 & .7 \\
\hline Total & & & 26.0 \\
\hline
\end{tabular}

1Both Vaccinium Vitis-idaea and Vaccinium uliginosum.

by Vaccinium Vitis-idaea berries (13.5 per cent) which had remained on plants from the previous fall. Diptera, from 7 families, was third (11.1 per cent) and made up 43 per cent of the invertebrate matter.

Four of the 33 crops examined contained no food. The 3 fullest crops held $112.0,94.8$, and $93.6 \mathrm{mg}$ dry weight. From this, we conclude that a crop filled to maximum capacity will hold approximately $100 \mathrm{mg}$ of oven dry-weight of food.

Caloric values for the most common food items representing 84.5 per cent of the total oven dry weight of the 33 crops have similar energy values with a mean of $4.71 \mathrm{kcal} . / \mathrm{gram}$ dry weight (Table 4). Therefore, by filling their crop once, chicks obtain approximately $0.47 \mathrm{kcal}$. of energy.

ENERGY REQUIRED. Metabolizable energy requirements have been computed for an 18-gram chick, representative of the period from hatch to 3 days when yolk is still present, and for a 30 -gram chick, representative of the immediate 
TABLE 4. Caloric values of principal food items of rock ptarmigan chicks.

\begin{tabular}{|c|c|}
\hline Item & $\begin{array}{l}\text { Caloric value }{ }^{1} \text { (kcals. } \\
\text { per gram ash free dry } \\
\text { weight) }\end{array}$ \\
\hline $\begin{array}{l}\text { Moss capsules } \\
\text { Vaccinium flowers }{ }^{2} \\
{\text { Vaccinium } \text { berries }^{2}}_{\text {Leaf fragments }} \\
\text { Polygonum viviparum bulbils } \\
\text { Diptera adults }\end{array}$ & $\begin{array}{l}4.37 \\
4.58 \\
4.46 \\
4.39 \\
4.75 \\
5.74 \\
\end{array}$ \\
\hline Mean & $\overline{4.71}$ \\
\hline
\end{tabular}

1 Each value is a mean of 3 determinations, varying by a maximum of 0.3 .

2Both Vaccinium Vitis-idaea and Vaccinium uliginosum.

post-yolk period. This has been calculated in two ways: We followed Stiven's (1961) approach for blue grouse chicks, substituting ptarmigan chick weights (18 and 30 grams) and daily growth rates (3.0 grams for the younger and 5.5 grams for the older chick [Table 5]). Growth rates were calculated from captive rock ptarmigan chicks (Theberge 1971). As shown in Table 5, total metabolizable energy requirements are 10.6 and $15.5 \mathrm{kcal}$. per day for the 18- and 30-gram chicks respectively.

Secondly, we converted the metabolizable energy requirement figure of 26.1 kcal. per day given by Kleiber and Dougherty (1934) for a 65 gram domestic chick to $0.40 \mathrm{kcal}$. per gram per day, and multiplied by the weight of our 18and 30-gram chicks respectively. Kleiber and Doughterty's figure applied to an ambient temperature of $38^{\circ} \mathrm{C}$. which is representative of the temperature chicks experience while being brooded.

Results from both methods represent the metabolizable energy requirement. Digestive efficiency has not been reported for rock ptarmigan chicks. However, West (1968) calculated from data on captive and wild adult willow ptarmigan (Lagopus lagopus) that efficiency of digestion in the wild was about 45 per cent.

TABLE 5. Metabolizable energy requirements of an 18 and 30 gram chick in thermoneutral conditions.

\begin{tabular}{lccccc}
\hline & \multicolumn{5}{c}{ Energy requirements (kcal./24 hours) } \\
& Basal $^{2}$ & Resting $^{3}$ & Activity $^{4}$ & $\begin{array}{c}\text { Total } \\
\text { growth }\end{array}$ & metabolizable $^{\mathbf{5}}$ \\
\hline 18 grams & 3.0 & 3.8 & 1.5 & 5.3 & 10.6 \\
30 grams & 5.0 & 6.3 & 2.5 & 6.7 & 15.5 \\
\hline
\end{tabular}

1 Calculation of all values after Stiven (1961).

${ }^{2}$ From equation $\mathrm{Y}=0.167 \mathrm{X}$ where $\mathrm{Y}=$ basal metabolism and $\mathrm{X}=$ weight.

3From equation $Y=0.21 X$ where $Y=$ resting metabolism and $X=$ weight.

${ }^{4}$ Activity value is 50 per cent of basal (Stiven 1961).

5From caloric values for protein and fat, contributing respectively approximately 15 and 4 per cent of weight gain, plus 30 per cent for energy to produce growth.

6 Sum of resting, activity and total growth. 
TABLE 6. Total energy intake requirements of rock ptarmigan chicks in thermoneutral conditions (kcal./24 hrs.).

\begin{tabular}{lcc}
\hline \multirow{2}{*}{ Weight } & \multicolumn{2}{c}{ Method } \\
\cline { 2 - 3 } & Stiven $^{1}$ & $\begin{array}{c}\text { Kleiber and } \\
\text { Dougherty }^{2}\end{array}$ \\
\hline 18 grams & 23.6 & 16.0 \\
30 grams & 34.4 & 26.7 \\
\hline
\end{tabular}

1After Stiven (1961).

2After Kleiber and Dougherty (1934).

This was confirmed recently in wild adults by Moss (in press). Using an assumed 45 per cent efficiency here, total daily energy intake requirements from previous calculations of metabolizable energy using Kleiber and Dougherty's data become $16.0 \mathrm{kcal}$. for the 18 -gram chick, and $26.7 \mathrm{kcal}$. for the 30-gram chick (Table 6). Slightly higher values result from use of Stiven's method (Table 6). These figures apply only to thermoneutral conditions.

While foraging, chicks are usually subjected to ambient temperatures below the critical temperature. However, ptarmigan chicks only a day or two old are incapable of increasing their metabolic rate significantly in response to cold (Anvik 1969). Therefore, for an 18-gram chick, the calculations made under thermoneutral conditions as described above are applicable to both brooding and foraging periods.

When 30 grams, chicks will increase their metabolic rate in response to temperatures below the critical temperature (Anvik 1969). An estimate of additional energy output can be obtained from Anvik's observation that 25-gram ptarmigan chicks experiencing $10^{\circ} \mathrm{C}$. in a cold chamber were unable to increase their resting metabolic rate above $0.9 \mathrm{kcal}$. per hour. Converting this to energy the chick must gather from its feed by using the 45 per cent digestive efficiency figure, results in an additional requirement of $2.0 \mathrm{kcal}$. per hour. Therefore, a 30-gram chick's total daily energy requirement is that required under thermoneutral conditions (26.7 to $34.4 \mathrm{kcal}$.), plus an additional approximately $2.0 \mathrm{kcal}$. per hour for periods of foraging in the cold.

\section{DISCUSSIONS AND CONCLUSIONS}

Dealing first with the 18-gram chick (between 1 and 3 days old), under the most inclement weather conditions observed, the amount of time available during the day to feed fell to 6 minutes per hour. On the basis of our observation that chicks were brooded continuously between 00:25 and 01:55 (observation 7, Table 2), plus incidental observations made of foraging chicks, we believe that foraging ceases for no longer than 8 hours (21:00 to 05:00), and very likely less. At a foraging rate of 6 minutes per hour for 16 hours, chicks would have 96 minutes in 24 hours to obtain their 16.0 to $23.6 \mathrm{kcal}$. energy requirement. Since the maximum crop load contained $0.47 \mathrm{kcal}$. a chick must obtain the equivalent of between 34 and 50 crop loads in 96 minutes, or 1 crop load every 2 to 3 minutes. 
To assess whether this feeding rate is realistic, we noted that the 3 fullest crops contained 54, 30, and 12 items. The crop with 12 items contained four Vaccinium berries. Since berries were not common in crops (Table 3), the other two figures, 54 and 30 are more representative. To obtain 30 items in 2 to 3 minutes requires a feeding rate of 1 successful peck every 4 to 6 seconds, kept up continuously for the 2 to 3 minutes. Theoretically this is possible. This is backed up by observations made in both captivity and the wild with a stop-watch that chicks peck at approximately 3 times that rate.

We conclude that even in inclement weather, very young chicks have sufficient time to gather their full energy requirement, without having to rely on stored energy in their yolk sac. However, of possible significance is whether or not chicks can empty their crops again in the interval between foraging periods. The yolk sac, present in very young chicks, may be viewed as necessary because of a limitation imposed by digestive rate. Alternatively, it is an adaptation to weather more severe than recorded over 10 years at Eagle Creek.

The 30-gram chick, representing the 4 to 5 day period after hatching, must obtain all of its energy from food since its yolk supply is exhausted, despite the amount of food eaten at an earlier age (Marcstrom 1960). Subcutaneous fat is meagre on rock ptarmigan chicks, and probably does not supply any energy.

We can estimate the foraging time required under adverse conditions similar to those experienced by the 18-gram chick, by basing our calculations on the previous conclusion that 96 minutes per 24 hours was sufficient for an 18-gram chick. Table 6 shows that energy requirements have increased by a maximum of 67 per cent. This would increase the necessary foraging time to 160 minutes under thermo-neutral conditions. If, however, the ambient temperature is below the critical temperature, additional foraging time will be required to meet the greater energy demand. In this case, foraging time must increase by approximately 34 minutes, which is calculated as follows:

1) Chicks foraging for 160 minutes below the critical temperature are able to increase utilizable resting metabolism to a maximum of $0.9 \mathrm{kcal}$./hour (Anvik 1969), multiplied by 160 minutes $=2.40 \mathrm{kcal}$; 2) Adjusting for 45 per cent digestive efficiency $=5.34 \mathrm{kcal}$.; 3) Since a full crop contains approximately $0.47 \mathrm{kcal}$, the additional $5.34 \mathrm{kcal}$. will require 11.4 crop loads; 4) Since $1 \mathrm{crop}$ load can be obtained in approximately 3 minutes, foraging time required for 11.4 crop loads is 34 minutes.

The 30-gram chick, therefore, requires $160+34=194$ minutes of foraging time, or approximately twice that required by the 18-gram chick. Since effective homeothermy has almost been reached (Anvik 1969), it seems reasonable that chicks could double their foraging time. However, since a conclusion here is based on computed rather than observational data, we only tentatively suggest that when chicks are 30-grams, brooding does not affect their ability to obtain sufficient energy.

On a population level, no correlation exists between survival of rock ptarmigan chicks at Eagle Creek (hatch until the end of July) and weather (temperature, precipitation), during the 10 years of recorded data (Theberge 1971). There is no question that weather can kill chicks, but vagaries of weather do not do so 
frequently enough to account for the annual differences in observed survival of rock ptarmigan chicks.

In conclusion, brooding of chicks 1 to 3 days old did not limit foraging time to the point where chicks were unable to obtain sufficient energy, even when additional internal energy sources were neglected. For chicks 4 and 5 days old, we tentatively refuted the hypothesis that brooding adversely affected ability to obtain sufficient energy for survival. On a population basis over the 10 year period, weather is not correlated with chick mortality.

Vagaries in early chick survival, therefore, must be due to factors other than differences in post-hatch weather.

\section{ACKNOWLEDGEMENTS}

This investigation was supported by funds from the Alaska Department of Fish and Game and the National Research Council of Canada. Facilities at the University of Alaska were provided by the Institute of Arctic Biology. Robert B. Weeden, then with the Alaska Department of Fish and Game, supplied radio-tracking equipment and help in the field. J. F. Bendell, University of British Columbia, provided valuable comment. Mrs. Theberge carried out much of the laboratory analysis, and assistance was provided by a number of students, especially J. $O$. Anvik. To all these, we express our appreciation.

\section{REFERENCES}

ANvik, J. o. 1969. The development and maintenance of homeothermy in the rock ptarmigan (Lagopus mutus). Unpublished B.Sc. Thesis, University of British Columbia. 53 pp.

BOAG, D. A. 1966. Population attributes of blue grouse in southwestern Alberta. Canadian Journal of Zoology, 44(5): 799-814.

haUGen, R. K., M. J. LYNCH and T. C. ROBERTS. 1970. Summer temperatures in interior Alaska. USA CRREL Research Report 144,85 pp.

KLEIBER, M. and J. E. DOUGHERTY. 1934. The influence of environmental temperature on the utilization of food energy in baby chicks. Journal of General Physiology, 17: 701-26.

KOSKIMIES, J. 1962. Ontogeny of thermoregulation and energy metabolism in some gallinaceous birds. Transactions $V$ International Union of Game Biologists. 149-60.

LANCE, A. N. 1970. Movements of blue grouse on the summer range. The Condor, 72(4): 437-44.

MARCSTROM, v. 1960. Studies on the physiological and ecological background to the reproduction of the capercaillie (Tetrao urogallus Lin.) Viltrevy, 2: 1-69.

MARSHALL, W. H. 1960. Development and use of short wave radio transmitters to trace animal movements. St. Paul: University of Minnesota, 27 pp. Mimeo.

1963. Radiotracking of porcupines and ruffed grouse. In: Biotelemetry. New York: Pergamon Press. pp. 173-78.

MOss, R. In press. Nutrition and interspecific competition in Alaskan ptarmigan (Lagopus spp.). Ecology.

PHILlIPSON, J. 1964. A miniature bomb calorimeter for small biological samples. Oikos, 15: 130-39.

ROBEL, R. J. 1969. Movements and flock stratification within a population of blackcocks in Scotland. Journal of Animal Ecology, 38: 755-63.

STIVEN, A. E. 1961. Food energy available for and required by the blue grouse chick. Ecology, $42(3): 547-53$. 
THEBERge, J. B. 1971. Population fluctuation and changes in the quality of rock ptarmigan in Alaska. Unpublished Ph.D. Thesis, University of British Columbia. $186 \mathrm{pp}$.

WEEDEN, R. B. 1963. Management of ptarmigan in North America. Journal of Wildlife Management, 27: 673-83.

WEEDEN, R. B. 1968. Dates of first flowers of alpine plants at Eagle Creek, central Alaska. Canadian Field-Naturalist, 82: 24-31.

WeEden, R. B. and J. B. THEBerge. 1972. Dynamics of a Fluctuating Population of Rock Ptarmigan in Alaska. Proceedings of the XV International Ornithological Congress. pp. 90-106.

WEST. G. C. 1968. Bioenergetics of captive willow ptarmigan under natural conditions. Ecology, 49(6): $1035-45$.

ZWICKEL, F. C. 1967. Some observations of weather and brood behaviour in blue grouse. Journal of Wildlife Management, 31(3): 563-68. 